\title{
A Panel Data Analysis of the Impact of Chinese Foreign Direct Investment (FDI), Remittances and Foreign Aid on Human Capital Growth and Brain Drain in Africa
}

\author{
Odette Tougem Tasinda ${ }^{1}$, Tian $\mathrm{Ze}^{{ }^{*}}$, Sunday Adiyoh Imanche ${ }^{2}$ \\ ${ }^{1}$ Business School of Hohai University, Nanjing, China \\ ${ }^{2}$ Department of Economics, Faculty of Humanities Management and Social Sciences, Federal University, Wukari, Nigeria \\ Email: ‘tianze21@126.com, teodetta@yahoo.com, imanchesunday@hotmail.com
}

How to cite this paper: Tasinda, O.T., Ze, T. and Imanche, S.A. (2021) A Panel Data Analysis of the Impact of Chinese Foreign Direct Investment (FDI), Remittances and Foreign Aid on Human Capital Growth and Brain Drain in Africa. Journal of Data Analysis and Information Processing, 9, 175-188.

https://doi.org/10.4236/jdaip.2021.93012

Received: January 4, 2021

Accepted: August 23, 2021

Published: August 26, 2021

Copyright $\odot 2021$ by author(s) and Scientific Research Publishing Inc. This work is licensed under the Creative Commons Attribution International License (CC BY 4.0).

http://creativecommons.org/licenses/by/4.0/

\begin{abstract}
The main purpose of this research was to analyze the impact the Chinese foreign direct investment (FDI), remittances, and foreign aid have had to human capital growth (HCG) and brain drain. The study data were collected from five African countries (Nigeria, Kenya, Ghana, South Africa, and Morocco) from 2009 to 2018. Secondary sources were used in data collection, then autoregressive distributed lag (ARDL) modeling was used in the analysis. Before modelling was done, co-integration tests and panel unit were applied. The results revealed that Chinese FDI, remittances, and foreign aid had a significant and positive impact on HCG in the long but not the short-run. Besides, remittances, Chinese FDI, and foreign aid demonstrated significant negative impacts on brain drain in the long term, not in the short term. This study makes important practical and theoretical contributions about the roles of Chinese FDI, remittances, and foreign aid in the reduction of brain drain and the growth of human capital.
\end{abstract}

\section{Keywords}

Chinese Foreign Direct Investment (FDI), Remittances and Foreign Aid, Human Capital Growth, Africa Brain Drain, Autoregressive Distributed Lag (ARDL) Modeling

\section{Introduction}

Brain drain is referred to the depleting of the highly skilled individuals from developing countries to the other countries. This situation has recently caused a 
serious economic problem. Brain drain comes along with high costs and some negative consequences, which is now a burden to the African countries.

\subsection{Background of the Study}

Recent study has shown that over the past 25 years, most of the highly skilled and best trained individuals from Africa have migrated to the developed counties [1]. There are societal, institutional, economic, and financial costs that come along with Brain Drain. These costs end up increasing the pressure on African nations since these nations are also working towards overcoming the shortage of well-equipped. To fill this gap, African counties spend a huge part of their economic resources on developing human capital and the employment of individuals. Despite large investments in their human capital, the problem of brain drain in African countries has grown because a large portion of African nationals who study and work abroad do not tend to return to their homes after having received an education. The departure of capable individuals from Africa to developed countries consequently contributes to negative outcomes in a variety of spheres, especially for the countries of origin. For instance, the departure of doctors and other health professionals from African countries has negatively affected the medical fields in their home countries. Besides, researches have shown that many African countries are not able to address even basic social and health needs.

The adverse effects of brain drain in African countries become worse when its impact on economic growth and development is overlooked. Many scholars have suggested that a country's brain drain is followed by decline of it [2]. Existing studies on brain drain have focused primarily on outcomes related to economic growth and development. There has been limited research on the determinants of brain drain. Several researchers argue that FDI and foreign aid in the developing countries often result in greater prosperity and advancement in the host country. This is because FDI and foreign aid usually enhance skills, and innovation capabilities [3].

Furthermore, Chinese FDI, remittances, and foreign aid in African countries can help to improve the governments' ability to spend and invest in employment opportunities for the skilled individuals, who would be likely to migrate [4]. Another important factor that could impact a country's economic growth and prosperity is Human capital growth (HCG). Human capital growth is defined as the knowledge and labor increase through training and management. When there is an increase in human capital growth, the company's employees are likely going to enjoy increased capacity. Consequently, the employees will work efficiently towards achieving improved performance, and increased productivity.

The economic growth of any country heavily relies on the growth of human capital and technological development [5]. Unfortunately, many African countries have to face several challenges regarding their HCG due to limited capital, infrastructure, and facilities [6]. Developing countries need to grow human cap- 
ital to be able to pursue new opportunities and utilize the latest technologies. HCG has been linked to many benefits for the country, the corporate sector, and the overall economy because it contributes to greater productivity as well as increased capacity, profitability, and prosperity.

\subsection{Problem Statement}

There are relatively few studies that have investigated the factors that could increase or decrease brain drain in a given country [7]. However, the few studies that have examined the determinants of brain drain in African countries have never investigated the roles of Chinese foreign direct investment (FDI), remittances, and foreign aid, all of which could potentially contribute to a decrease in brain drain.

Secondly, the existing literature does not serve to adequately explain the mechanisms by which Chinese FDI, foreign aid, and remittances could reduce brain drain. The current study is therefore aiming to address this gap by analyzing the influence of Chinese FDI, remittances, and foreign aid on the brain drain in five African countries.

Thirdly, other several other studies have emphasized the significant role of HCG in the growth and prosperity of an economy [8]. However, little research on the same has been done to the African countries. The few conducted studies have focused primarily on the impact of HCG on the economy but did not offer any explanation of the factors that contributed to HCG in African countries. This gap will also be addressed in this study. Besides, the studies devoted to the impact of different factors on HCG in African countries. They did not examine the particular impacts of Chinese FDI, remittances, and foreign aid. As a means to address this gap in the literature, the third objective of this study was to analyze the influence of Chinese FDI, remittances, and foreign aid on HCG.

\section{Literature Review}

\subsection{The Solow Economic Growth Model}

The neo-classical theory of growth, the Solow economic growth model, was introduced by Robert Solow, as a means to discuss the determinants of economic growth in different regions of the world. Solow received a Nobel Prize for his achievements in economics in 1987. Solow explained that economic growth consisted of capital, labor, and technology. When capital investment is made, the economic growth rate is not permanent. Rather, it improves gradually because of the labor to capital ratio increases. The marginal product of the additional capital decreases and the overall economy returns to the long-term growth plan, in which the GDP of a country increases with the increase of the workforce in that particular country [9]. The growth becomes steady when the output, capital, and labor all increase at the same time. In other words, output per worker and capital per worker becomes constant. According to this theory, to increase the growth rate of a country, it would be crucial to increase the labor supply and increase 
the productivity of capital and labor. Additionally, technological advances play an important role in the growth rate of a country. Productivity growth depends on factors other than increases in capital investments.

\subsection{Impact of Chinese FDI on Human Capital Growth}

FDI is the investment made by businesses of one country in the businesses of another country to grow business and develop a long-lasting interest in the other country. The lasting interest usually involves $10 \%$ voting rights in the businesses of the host country. The investing country also has some control over the businesses of the host country. This may be achieved through the purchase of stocks in a business or company by the investor country. Additionally, the investing country's organization may open a branch or franchise of their firm in the host country. Studies have shown that FDI actually increases human and infrastructural development in the host country.

Economic policy often has been designed to attract FDI. FDI not only benefits the investing country but also produces benefits for the host country. The most important benefit of FDI in the host country is economic growth and development. The economic growth of any country depends on human capital growth and technological changes. Studies have shown that higher productivity leads to higher economic growth in a given country. The relationship between higher productivity and economic growth is clearly illustrated in the Solow model [10]. Chinese FDI in Africa should bring not only investments but also the latest technology to the host country. Therefore, FDI should lead to growth in human capital and, consequently, economic growth in Africa. We propose the following hypothesis:

H1: Chinese FDI has a significant positive impact on human capital growth in Africa.

\subsection{Impact of Remittances on Human Capital Growth}

Remittances are the money migrants earn in another country and send to family members in their home countries. The recipient family may use those remittances as they see fit [11]. For example, the recipient's family could invest the money in a financial endeavor that could result in the growth of capital in that receiving country. Alternatively, a recipient family could invest the money in the education of labor or employees that will increase human capital growth in that country. This increase in human capital growth ultimately would lead to the adoption of innovation and the latest technology, which would have a positive impact on the host country's economic growth. [12] noted that, in addition to money, migrants also transferred technological and innovative ideas to their countries of origin. When remittances were invested in the education of labor and people received technical or managerial training, they contribute to an increase in human capital growth [13] [14]. The Solow economic growth model has illustrated how remittances improved the economic conditions of a country 
[15]. In our study, African migrants working in China sent remittances to their families, and those remittances could have contributed to economic growth. We thus put forth the following hypothesis:

H2: Remittances have a significant positive impact on human capital growth in Africa.

\subsection{Impact of Foreign Aid on Human Capital Growth}

Foreign aid refers to the money that one country voluntarily transfers to another country in the form of a gift, grant, or loan. Foreign aid may be given for many purposes, the most important of which is growing in the economic conditions of the country that receives the aid [16]. Many countries sustain poor economies due to a lack of financial resources. This ultimately leads to lower capital, which is not in the better interests of that country. Therefore, the country attempts to forge good relations with developed countries or those with which they share relevant interests. Studies have shown that if good relations are built successfully, developed countries give aid to the developing countries to make their economic conditions better and to reduce poverty. That aid could be used to increase physical or human capital and can also be invested in the education of labor in the country to increase human capital. The aid also could be used to obtain the latest technology and train workers in the use of that technology. The Solow economic growth model could help to explain the impact of foreign aid on a country's human capital growth. We offer the following hypothesis:

H3: Foreign aid has a significant positive impact on human capital growth in Africa.

\subsection{Impact of Chinese FDI on Brain Drain}

Skilled and educated workers leave primarily because of a country's poor economic conditions as well as a lack of decent jobs and salaries. All these factors compel highly educated and skilled workers to migrate from their home country. This has a major negative impact on the migrant's own country, as the economy further suffers because of this exodus. Chinese FDI could help to reduce brain drain from Africa. We offer the following hypothesis:

H4: Chinese FDI has a significant negative impact on brain drain in Africa.

\subsection{Impact of Remittances on Brain Drain}

Remittances employed to develop businesses could help to improve the economic conditions of the country and decrease poverty and unemployment from the country. Skilled and educated workers who were able to secure financial benefits and opportunities remained in their country [17]. African people residing in China for work purposes send remittances to friends and family members, as opposed to countries, which ultimately improves the economic health of their home countries. In this way, the newly qualified and skilled workers would prefer to remain in their own country and contribute to its growth. We offer the 
following hypothesis:

H5: Remittances have a significant negative impact on brain drain in Africa.

\subsection{Impact of Foreign Aids on Brain Drain}

We offer the following hypothesis:

H6: Foreign aid has a significant negative impact on brain drain in Africa.

\section{Methodology}

\subsection{Sample and Data Collection}

The purpose of the present research is to analyze the impact of Chinese FDI, remittances, and foreign aid on HCG and brain drain in five selected African countries. An appropriate sample from the five countries was used in the study. Purposive sampling technique was used in the selection of the countries (Nigeria, South Africa, Morocco, Kenya, and Ghana). These five countries were selected for data collection because we believe they best represent the economic conditions in Africa. Data was collected for ten years from 2009 to 2018. After the ten years, there was sufficient data collected from these countries. This data was then used to analyze the impacts of Chinese FDI, remittances, and foreign aid on HCG and brain drain in Africa. Chinese investment in Africa was at a peak from 2009 to 2018. Panel data was used for the analysis. Data were collected from the World Bank database. The data in the World Bank database is collected using current reports gathered by the Bank's country management units, which includes data obtained from official sources of the countries in review [18].

\subsection{Definition and Measurement of Variables}

The following variables and their relationships were the focus of this study:

Dependent variables. "Human capital growth" (HCG) and "brain drain" (BD) were the two dependent variables. HCG was measured by calculating the proportion of skilled labor to total labor in each of the countries. "Brain drain" was measured by the "gross migration rate" (GMR) for each country.

Independent variables. "Chinese FDI", "remittances" (REM), and "foreign aid" (FA) represented the independent variables that were analyzed to examine the effects on brain drain and HCG. The proportion of Chinese FDI to total FDI was calculated for Nigeria, South Africa, Morocco, Kenya, and Ghana. A log of Chinese FDI (LCFDI) was used for the main analysis. The World Bank database also was used to obtain information on remittances and foreign aid in the selected countries and create a log of remittances (LREM) and log of foreign aid (LFA)

Control variable. "Gross domestic product" (GDP) was the control variable added to isolate the impact of independent variables on HCG and brain drain. This information also was obtained for each of the countries from the World Bank database. 


\subsection{Autoregressive Distributed Lag (ARDL) Modeling}

The analysis of the short-term and long-term impact of Chinese FDI, remittances, and foreign aid on HCG and the brain drain was conducted using ARDL modeling. The ARDL equations are the following:

$$
\begin{aligned}
\Delta H C G_{i t}= & \alpha_{i}+\sum_{j=1}^{m-1} \beta_{i j} \Delta H C G_{i, t-j}+\sum_{l=0}^{n-1} \varphi_{i l} \Delta C F D I_{i, t-l} \\
& +\sum_{r=0}^{p-1} \Upsilon_{i r} \Delta R E M_{i, t-r}+\sum_{u=0}^{q-1} \Upsilon_{i u} \Delta F A_{i, t-u} \\
& +\sum_{v=0}^{s-1} \theta_{i v} \Delta G D P_{i, t-v}+\delta_{1} H C G_{i, t-1}+\delta_{2} C F D I_{i . t-1} \\
& +\delta_{3} R E M_{i . t-1}+\delta_{4} F A_{i, t-1}+\delta_{5} G D P_{i . t-1}+\varepsilon_{1 i, t} \\
\Delta B D_{i t}= & \alpha_{i}+\sum_{j=1}^{m-1} \beta_{i j} \Delta B D_{i, t-j}+\sum_{l=0}^{n-1} \varphi_{i l} \Delta C F D I_{i, t-l} \\
+ & \sum_{r=0}^{p-1} \Upsilon_{i r} \Delta R E M_{i, t-r}+\sum_{u=0}^{q-1} \Upsilon_{i u} \Delta F A_{i, t-u} \\
& +\delta_{1} B D_{i . t-1}+\delta_{2} C F D I_{i . t-1}+\delta_{3} R E M_{i . t-1}+\delta_{4} F A_{i, t-1}+\varepsilon_{1 i, t}
\end{aligned}
$$

The prerequisites for the ARDL analysis were fulfilled by running panel unit root and co-integration tests. The panel unit root test was conducted to check the stationarity of the panel data. Once the stationarity of the data was confirmed, the presence of co-integration was checked:

$$
\begin{aligned}
& H_{0}: \delta_{1}+\delta_{2}+\delta_{3}+\delta_{4}+\delta_{5}=0 \\
& H_{1}: \delta_{1}+\delta_{2}+\delta_{3}+\delta_{4}+\delta_{5} \neq 0
\end{aligned}
$$

The null hypothesis of the co-integration test assumed that "there is no co-integration in the data". The alternative hypothesis assumed that "there is co-integration in the data". Following both tests, the long-term effects of Chinese FDI, remittances, and foreign aid on HCG and brain drain were assessed using the following equations:

$$
\begin{gathered}
H C G_{i t}=\mu_{i}+\sum_{j=1}^{m-1} \lambda_{1 j} H C G_{i, t-j}+\sum_{l=0}^{n-1} \lambda_{2 j} C F D I_{i, t-l}+\sum_{r=0}^{p-1} \lambda_{3 j} R E M_{i, t-r} \\
+\sum_{u=0}^{q-1} \lambda_{4 j} F A_{i, t-u}+\sum_{v=0}^{s-1} \lambda_{4 j} G D P_{i, t-v}+v_{1 i, t} \\
B D_{i t}=\mu_{i}+\sum_{j=1}^{m-1} \lambda_{1 j} B D_{i, t-j}+\sum_{l=0}^{n-1} \lambda_{2 j} C F D I_{i, t-l} \\
\quad+\sum_{r=0}^{p-1} \lambda_{3 j} R E M_{i, t-r}+\sum_{u=0}^{q-1} \lambda_{4 j} F A_{i, t-u} v_{1 i, t}
\end{gathered}
$$

The "coefficients of long-term relationships" were kept constant for all the countries. The short-term effects were checked through "error correction terms", as follows:

$$
\begin{aligned}
\Delta H C G_{i t}= & \alpha_{i}+\sum_{j=1}^{m-1} \beta_{i j} \Delta H C G_{i, t-j}+\sum_{l=0}^{n-1} \varphi_{i l} \Delta C F D I_{i, t-l} \\
& +\sum_{r=0}^{p-1} \Upsilon_{i r} \Delta R E M_{i, t-r}+\sum_{u=0}^{q-1} \Upsilon_{i u} \Delta F A_{i, t-u} \\
& +\sum_{v=0}^{s-1} \theta_{i v} \Delta G D P_{i, t-v}+a E C T_{t-1}+\varepsilon_{1 i, t} \\
\Delta B D_{i t}= & \alpha_{i}+\sum_{j=1}^{m-1} \beta_{i j} \Delta B D_{i, t-j}+\sum_{l=0}^{n-1} \varphi_{i l} \Delta C F D I_{i, t-l} \\
& +\sum_{r=0}^{p-1} \Upsilon_{i r} \Delta R E M_{i, t-r}+\sum_{u=0}^{q-1} \theta_{i u} \Delta F A_{i, t-u}+a E C T_{t-1}+\varepsilon_{1 i, t}
\end{aligned}
$$

In Equations (5) and (6), $\varepsilon_{k i, t}$ is the "residual" while $E C T_{t-1}$ is the "error 
correction term," which indicates the short-term relationship between variables.

\subsection{Panel Unit Root Test}

The unit root test proved particularly important in this study, which included macroeconomic data. The ADF Fisher Chi-square (ADF Fisher) and Levin, Lin, and Chi (LLC) unit root tests were conducted.

\section{Findings}

The analysis was conducted with Eview 10 and consisted of descriptive analysis, panel unit root tests, co-integration tests, and the ARDL approach.

\subsection{Descriptive Statistics}

Descriptive statistics of the data collected were generated to check the data normality and adequacy. Key indicators that were considered to check the normality and appropriateness of the data were mean value, minimum value, maximum value, skewness, and kurtosis. The formulas used to get these parameters are as shown below;

$$
\begin{aligned}
\text { Mean Value } & =\frac{\text { Sum of all data points }}{\text { Number of data points }} \\
& =\text { Assumed Mean }+\frac{\text { Sum of all deviations }}{\text { Number of data points }}
\end{aligned}
$$

Minimum Value:

Given the eq. $y=a x^{2}+b x+c$

$$
\min =c-b^{2} / 4 a
$$

Maximum Value:

Given that; $y=a x^{2}+b x+c$

$$
\max =c-\left(b^{2} / 4 a\right)
$$

Skewness:

$$
\hat{u}_{3}=\frac{\sum_{1}^{N}\left(X_{i}-\bar{X}\right)^{3}}{(N-1) * \partial^{3}},
$$

where $N=$ No of Variables;

$\hat{u}_{3}=$ Skewness;

$X_{i}=$ Random Variable;

$\bar{X}=$ Mean of the distribution;

$\partial=$ Variance.

Kurtosis:

Population Kurtosis ( $k$ )

$$
k=n \frac{\sum_{i=1}^{n}\left(x_{i}-x_{a v g}\right)^{4}}{\left(\sum_{i=1}^{n}\left(x_{i}-x_{\text {avg }}\right)^{2}\right)^{2}}
$$




\section{Sample Kurtosis}

$$
k=\frac{n(n+1)(n-1)}{(n-2)(n-3)} \frac{\sum_{i=1}^{n}\left(x_{i}-x_{\text {avg }}\right)^{4}}{\left(\sum_{i=1}^{n}\left(x_{i}-x_{\text {avg }}\right)^{2}\right)^{2}}
$$

The results are presented in Table 1.

As Table 1 illustrates, the mean values of Chinese FDI, remittances, foreign aid, HCG, brain drain, and GDP all were within the data range; there were no outliers for any of the variables. The standard deviation indicated acceptable variation in the data. The skewness of all the variables also was within a threshold range, greater than -1 and less than +1 . The normality of the data was proved through kurtosis for all of the variables, $>1$ and $<3$ for all. Hence, the current data is normal and acceptable for use for further analysis.

\subsection{Panel Unit Root Test}

Table 2 illustrates the results of the panel unit root tests. The ADF and LLC tests indicated that all of the variables demonstrated unit root at first difference maximum; CFDI, REM, FA, HCG, BD, and GDP are stationery and therefore

Table 1. Descriptive statistics.

\begin{tabular}{ccccccc}
\hline & LCFDI & LREM & LFA & HCG & BD & GDP \\
\hline Mean & 20.00395 & 21.83167 & 21.26248 & 0.570559 & 0.333039 & 4.328047 \\
Median & 19.95482 & 21.60753 & 21.29739 & 0.573956 & 0.315153 & 4.236909 \\
Maximum & 24.32781 & 23.91420 & 23.69243 & 0.947344 & 0.646643 & 14.04712 \\
Minimum & 16.45106 & 18.55570 & 18.64701 & 0.217110 & 0.113988 & -1.616869 \\
Std. Dev. & 1.348765 & 1.340310 & 0.614980 & 0.163566 & 0.116038 & 2.889136 \\
Skewness & 0.501222 & -0.137986 & -0.290191 & 0.397258 & 0.424701 & 0.569531 \\
Kurtosis & 2.339998 & 2.489945 & 2.09800 & 2.955410 & 2.741147 & 2.226805 \\
\hline
\end{tabular}

BD, brain drain; GDP, gross domestic product; HCG, human capital growth; LCFDI, log of Chinese foreign direct investment; LFA, log of foreign aid; LREM, log of remittances.

Table 2. Panel unit root test.

\begin{tabular}{|c|c|c|c|c|}
\hline \multirow{2}{*}{ Variables } & \multicolumn{2}{|c|}{ ADF test } & \multicolumn{2}{|c|}{ LLC test } \\
\hline & At level & $1^{\text {st }}$ difference & At level & $1^{\text {st }}$ difference \\
\hline CFDI & 10.5305 & $5.48837^{\star *}$ & $-1.98786^{\star}$ & $3.27146^{\star * *}$ \\
\hline REM & $24.7995^{\star *}$ & $25.1069^{* *}$ & $-4.86111^{\star * *}$ & $-5.56217^{\star * *}$ \\
\hline FA & 7.62084 & $13.4382^{\star * *}$ & 0.73789 & $-0.42243^{\star \star}$ \\
\hline GDP & 16.4023 & $33.4190^{\star * *}$ & $-1.99945^{*}$ & $-4.51880^{\star * *}$ \\
\hline $\mathrm{HCG}$ & 8.33212 & $10.2222^{\star}$ & $-3.43393^{\star \star \star}$ & $-1.74555^{\star}$ \\
\hline $\mathrm{BD}$ & 3.46846 & $26.8079^{* *}$ & 0.64880 & $-5.37179^{\star * *}$ \\
\hline
\end{tabular}

Note: ${ }^{* *}$ indicates $p$-value $<0.001,{ }^{* *}$ indicates $p$-value $<0.01{ }^{*}$ indicates $p$-value $<0.05$. ADF, Fisher Chi-square; BD, brain drain; CFDI, Chinese foreign direct investment; FA, foreign aid; GDP, gross domestic product; HCG, human capital growth; LLC, Livin, Lin and Cchi; REM, remittances. 
the ARDL modeling may be applied to both series I(0) and I(1). Hence, the condition for ARDL modeling was fulfilled.

\subsection{Co-Integration Analysis}

The results regarding stationarity suggested that there must be co-integration among the variables. Table 3 illustrates the results of the co-integration test. The $\mathrm{P}$-value for the Group PP-Statistic is $<0.05$; thus, the null hypothesis is rejected. Hence, there is co-integration between dimensions. However, no co-integration within dimensions was proved. The condition for ARDL modeling is proved; thus, the next step is to apply ARDL modeling.

\subsection{ARDL Modeling}

An autoregressive distributed lag (ARDL) is a model that is based on the Ordinary Least Square (OLS). This model can be applied in non-ordinary time series, and the time series that has mixed integration order. This model is used to forecast and disentangle the long-run relationships from the existing short-term dynamics.

Below is the process that is followed when constructing an ARDL model:

1) Determine the existence of the long-run relationships in the available variables. This relationship is often tested through computation of the Bound F-Statistic. The Bound F-Statistic is done on each of the variable at a go, while the other variables are held as exogenous variables. This step leads to testing the hypothesis.

2) Choosing of the Lag length that is appropriate for ARDL model. This step involves estimating the long run estimators of the ARDL model. If there exists a long-run relationship between the available variables, whilst the hypothesis shows no long run relations, then the hypothesis is accepted at this point.

Table 3. Co-integration test.

\begin{tabular}{ccccc}
\hline \multicolumn{5}{c}{ Alternative hypothesis: common AR coefficients (within-dimension) } \\
\hline & $\underline{\text { Statistic }}$ & $\underline{\text { Prob. }}$ & $\underline{\text { Statistic }}$ & $\underline{\text { Prob. }}$ \\
\hline Panel v-Statistic & -0.847992 & 0.8018 & -1.990455 & 0.9767 \\
Panel rho-Statistic & 2.430369 & 0.9925 & 2.432539 & 0.9925 \\
Panel PP-Statistic & -0.800204 & 0.2118 & -0.205617 & 0.4185 \\
Panel ADF-Statistic & 0.230108 & 0.5910 & -0.877033 & 0.1902 \\
\hline Alternative hypothesis: individual AR coefficients (between-dimension) & \\
\hline Statistic & $\underline{\text { Prob. }}$ & & \\
\hline Group rho-Statistic & 3.310798 & 0.9995 & & \\
Group PP-Statistic & -1.690387 & 0.0455 & & \\
Group ADF-Statistic & 0.100975 & 0.5402 &
\end{tabular}

ADF, Fisher Chi-square; AR, Autogression; PP, Panel Proof. 
3) Reparametizing the ARDL model to the error correlation model. Remember that there are chances of getting spurious results when the variables that are non-stationary. Differencing the data to get variables that are stationary can be used to solve this problem. Therefore, ARDL model can be estimated by using OLS method.

In this study, two models were tested: one with a dependent variable of HCG and a second with a dependent variable of brain drain. Table 4 shows the first model.

Table 4 illustrates the short- and long-term effects of Chinese FDI, remittances, and foreign aid on HCG. Chinese FDI, remittances, and foreign aid had significant positive impacts on HCG in the long-term; the $p$-values all are $<0.05$ and the $t$-statistic is greater than $\mathrm{t}$-tabulated. However, none of these three independent variables indicated any significant impact on HCG in the short-run. Chinese FDI, remittances, and foreign aid positively influenced the HCG in Africa in the long-term. Similar results were found for the control variables; GDP showed significant but negative impacts on HCG in the long-term, but it showed no significant impact on HCG in the short-run. Table 5 presents the results of the ARDL regression with the dependent variable of the brain drain.

Chinese FDI has a negative and significant long-term impact on brain drain; the $p$-value is $<0.05$ and the $t$-statistic is greater than $\mathrm{t}$-tabulated. Similarly, remittances and foreign aid also significantly and negatively influenced the brain

Table 4. ARDL results (dependent variable: HCG).

\begin{tabular}{ccccc}
\hline Variable & Coefficient & Std. error & t-statistic & Prob. $^{*}$ \\
\hline Long run equation & & \\
LCFDI & 0.027147 & 0.006272 & 4.328564 & 0.0005 \\
LREM & 0.154803 & 0.029025 & 5.333398 & 0.0001 \\
LFA & 0.078192 & 0.020299 & 3.851956 & 0.0014 \\
GDP & -0.035698 & 0.001132 & -31.53052 & 0.0000 \\
\hline Short-run & equation & & \\
\hline COINTEQ01 & -0.340526 & 0.094664 & -3.597196 & 0.0024 \\
D (LCFDI) & 0.014354 & 0.012649 & 1.134735 & 0.2732 \\
D (LREM) & -0.105999 & 0.070658 & -1.500168 & 0.1530 \\
D (LFA) & -0.092347 & 0.049569 & -1.863006 & 0.0809 \\
D (GDP) & 0.003134 & 0.006098 & 0.514001 & 0.6143 \\
C & 0.718114 & 0.214972 & 3.340493 & 0.0041 \\
\hline Mean dependent var & 0.036087 & S.D. dependent var & 0.027236 \\
S.E. of regression & 0.010361 & Akaike info criterion & -6.343147 \\
Sum squared residual & 0.001718 & Schwarz criterion & -5.042971 \\
Log likelihood & 192.5787 & Hannan-Quinn criterion & -5.848032 \\
\hline
\end{tabular}

ARDL, autoregressive distributed lag; GDP, gross domestic product; HCG, human capital growth; LCFDI, $\log$ of Chinese foreign direct investment; LFA, log of foreign aid; LREM, log of remittances. 
Table 5. ARDL results (Dependent variable: BD).

\begin{tabular}{ccccc}
\hline Variable & Coefficient & Std. error & t-statistic & Prob. $^{*}$ \\
\hline Long run equation & & \\
\hline LCFDI & -0.051217 & 0.011844 & -4.324144 & 0.0003 \\
LREM & -0.027848 & 0.008625 & -3.228641 & 0.0039 \\
LFA & -0.081115 & 0.012872 & -6.301441 & 0.0000 \\
\hline COINTEQ01 & Short-run equation & & \\
D (LCFDI) & -0.178636 & 0.112640 & -1.585907 & 0.1270 \\
D (LREM) & 0.006080 & 0.019492 & 0.311908 & 0.7580 \\
D (LFA) & 0.181657 & 0.102386 & 1.774240 & 0.0899 \\
C & -0.049256 & 0.063729 & -0.772889 & 0.4478 \\
Mean dependent var & -0.201010 & 0.125998 & -1.595345 & 0.1249 \\
S.E. of regression & -0.018226 & S.D. dependent var & 0.036973 \\
Sum squared residuals & 0.036088 & Akaike info criterion & -4.346051 \\
Log likelihood & 0.028651 & Schwarz criterion & -3.275318 \\
\hline
\end{tabular}

ARDL, autoregressive distributed lag; $\mathrm{BD}$, brain drain; LCFDI, log of Chinese foreign direct investment; LFA, log of foreign aid; LREM, log of remittances.

drain in the long run. None of the independent variables showed any significant impact on brain drain in the long-term. Hence, Chinese FDI, remittances, and foreign aid significantly reduced the brain drain in the long-term while they did not affect the brain drain in the short-run.

\section{Discussion}

H1 of the current study was proved; Chinese FDI had a significant positive impact on human capital growth in Africa. The positive impact of Chinese FDI on HCG in Africa was due to the potential for Chinese FDI to improve the economic development in these African countries. Other scholars arrived at the same conclusion [10]. H2, remittances impact HCG, also was proved. Remittances helped to build infrastructure and create capital, both of which are needed for HCG in Africa. These results also were consistent with other researchers' findings [12]. H3, foreign aid impacts HCG, was proved. These findings provide further evidence of conclusions from previous studies by.

$\mathrm{H} 4$, which is about the impact of Chinese FDI on brain drain, was also proved. The findings revealed that Chinese FDI played an important role in reducing brain drain from Africa because Chinese FDI enhanced the country's infrastructure and employment. Consequently, people stayed in their home country rather than migrated to other countries. $\mathrm{H} 5$ of this study, which was remittances have a significant negative impact on brain drain in Africa, also was proved. Remittances increased the availability of capital and employment opportunities and thereby contributed to a decrease in migration. Therefore, remittances re- 
duced brain drain in Africa. These findings also reaffirm those from previous studies [19]. The final hypothesis was about the impact of foreign aid on brain drain; this hypothesis also was proved. Studies by Asongu and Tchamyou also had suggested that foreign aid led to a decrease in brain drain.

\section{Conclusions}

The current study is of great importance for both researchers and practitioners because it contributes empirical evidence of the key role played by Chinese FDI, remittances and foreign aid in the reduction of brain drain and the elevation of HCG. An understanding of this role could serve to inform policy as well as development strategies and decisions made in African countries.

The current study examined the impact of Chinese FDI, foreign aid, and remittances on brain drain and HCG in only five African countries. Other countries on the continent could produce different results. Future studies could include a larger sample of African countries. The findings are also limited to African countries. Future research could examine these relationships in the context of other regions and continents.

\section{Conflicts of Interest}

The authors declare no conflicts of interest regarding the publication of this paper.

\section{References}

[1] Driffield, N. and Jones, C. (2013) Impact of FDI, ODA, and Migrant Remittances on Economic Growth in Developing Countries: A Systems Approach. The European Journal of Development Research, 25, 173-196. https://doi.org/10.1057/ejdr.2013.1

[2] Okeke, E.N. (2013) Brain Drain: Do Economic Conditions "Push" Doctors out of Developing Countries? Social Science and Medicine, 98, 169-178.

https://doi.org/10.1016/j.socscimed.2013.09.010

[3] Moran, T.H. (2012) Foreign Direct Investment and Development. In: Ritzer, G., Ed., The Wiley-Blackwell Encyclopedia of Globalization, John Wiley and Sons, Hoboken, 121. https://doi.org/10.1002/9780470670590.wbeog217

[4] Irdam, D. (2012) The Impact of Remittances on Human Development: A Quantitative Analysis and Policy Implications. Sociology, 5, 74-95.

https://www.researchgate.net/profile/Aysen Ustubici/publication/274183977 https://doi.org/10.14254/2071-789X.2012/5-1/6

[5] Cuaresma, J.C. (2017) Income Projections for Climate Change Research: A Framework Based on Human Capital Dynamics. Global Environmental Change, 42, 226-236. https://doi.org/10.1016/j.gloenvcha.2015.02.012

[6] Hakeem, I.M. (2010) Banking Development, Human Capital, and Economic Growth in Sub-Saharan Africa (SSA). Journal of Economic Studies, 37, 557-577. https://doi.org/10.1108/01443581011075479

[7] Foo, G. (2017) Quantifying the Malaysian Brain Drain and an Investigation of Its Key Determinants. Malaysian Journal of Economic Studies, 48, 93-116. https://mjes.um.edu.my/article/view/2846 
[8] Fleisher, B., Li, H. and Zhao, M.Q. (2010) Human Capital, Economic Growth, and Regional Inequality in China. Journal of Development Economics, 92, 215-231. https://doi.org/10.1016/j.jdeveco.2009.01.010

[9] Rahman, M.S. and Shahari, F. (2017) The Nexus between Financial Integration and Real Economy: Solow-Growth Model Concept. Research in International Business and Finance, 42, 1244-1253. https://doi.org/10.1016/j.ribaf.2017.07.062

[10] Ali, M. and Malik, I.R. (2017) Impact of Foreign Direct Investment on Economic Growth of Pakistan. Proceedings of the Asian Multidisciplinary Conference, Johor, 30-31 December 2017, 51-70. https://papers.ssrn.com/sol3/papers.cfm?abstract id=3104717

[11] Adams, S. and Klobodu, E.K.M. (2016) Remittances, Regime Durability, and Economic Growth in Sub-Saharan Africa (SSA). Economic Analysis and Policy, 50, 1-8. https://doi.org/10.1016/j.eap.2016.01.002

[12] Comes, C.A., Bunduchi, E., Vasile, V. and Stefan, D. (2018) The Impact of Foreign Direct Investments and Remittances on Economic Growth: A Case Study in Central and Eastern Europe. Sustainability, 10, 238. https://doi.org/10.3390/su10010238

[13] Nahar, F.H. and Arshad, M.N.M. (2017) Effects of Remittances on Poverty Reduction: The Case of Indonesia. Journal of Indonesian Economy and Business, 32, 163. https://doi.org/10.22146/jieb.28678

[14] Olutayo, A.O. (2017) Money Drain, the Diaspora Remittance Issues and Higher Education in Nigeria. Journal of International Mobility, 5, 13-42. https://doi.org/10.3917/jim.005.0013

[15] Dastidar, S. G. (2017) Impact of Remittances on Economic Growth in Developing Countries: The Role of Openness. Global Economy Journal, 17, 33-44. https://doi.org/10.1515/gej-2016-0066

[16] Arndt, C., Jones, S. and Tarp, F. (2016) What Is the Aggregate Economic Rate of Return to Foreign Aid? The World Bank Economic Review, 30, 446-474. https://doi.org/10.1093/wber/lhv033

[17] Salahuddin, M. and Gow, J. (2015) The Relationship between Economic Growth and Remittances in the Presence of Cross-Sectional Dependence. The Journal of Developing Areas, 49, 207-221. https://doi.org/10.1353/jda.2015.0007

[18] Flora, U., Tian, Z. and Ezezue, J.O. (2020) FDI (Foreign Direct Investments) as a Determinant for the Economic Growth of Nigeria (2009-2018). Open Journal of Business and Management, 8, 770-782. https://doi.org/10.4236/ojbm.2020.82047

[19] Meyer, D. and Shera, A. (2017) The Impact of Remittances on Economic Growth: An Econometric Model. Economia, 18, 147-155. https://doi.org/10.1016/j.econ.2016.06.001 